\title{
School Library Development Plan Application Based on Web
}

\author{
Abri Hadi ${ }^{1}$, Mukramin $^{2}$, Ramdana $^{3}$ \\ ${ }^{1}$ Fakultas Kesehatan Prodi Kebidanan, Institut Kesehatan Dan Bisnis Kurnia Jaya Persada, Palopo, Indonesia \\ ${ }^{2}$ Fakultas Teknik Prodi Teknik Informatika, UNANDA, Palopo, Indonesia \\ ${ }^{3}$ Fakultas Ilmu Komputer, Universitas Megarezky, Makassar, Indonesia \\ E-mail: ${ }^{1}$ abri.salma21@gmail.com, ${ }^{2}$ minkbutsi@gmail.com, ${ }^{3}$ imuda931@gmail.com
}

\begin{abstract}
Libraries are part of learning resources that must be owned by every school and college. Library make students seek knowledge easily. Vocational High School State (SMK) 2 Luwu

Keywords

Web; Library; PHP; MySQL; Waterfall is one of the secondary schools that has not implemented a website-based system. This is because the library of SMK Negeri 2 Luwu still uses a manual system. As in lending and returning services, they still use a recording system in the borrowing book. In addition, when there are new books added, the librarian does not record the book data, only gives the ID to the book and immediately stores it on the appropriate shelf in the book category. The method used in this research is the waterfall method. This application is designed using the UML model and built using the PHP programming language and MySQL database.
\end{abstract}

\section{INTRODUCTION}

The human need for technology today cannot be separated from the life of each person. Because with any technology we can easily get information. There are many ways to access or get information through the internet, one of which is accessing the web. The web is a technology that has been used for a long time to access information, but there are still many agencies that have not implemented the web for administrative or other need (Fatimah \& Elmasari, 2018) (Hadi, 2020) (Dani \& Kariadi, 2018). The use of websites in conveying information is very helpful and useful for institutions or companies. Submission of information with the website is very fast and can be done from anywhere (Suppa \& Saldi, 2018) (Apriyanto, 2018). Not limited by place, time and cost (Firman, Wowor \& Najoan, 2016)

The library is one part of educational institutions as a learning resource that must be owned by every school, college. Because students easily seek knowledge through the library (Hutagalung \& Arif, 2018). The school library is a repository of knowledge in schools, until now the library is less attractive to students to read books or look for book references. Why is that, because students or students prefer to find information via the internet that is easy to get (Pasaaribu, 2021).

Seeing the phenomenon of implementing information systems in school libraries, it can be said that there are still many schools that use manual systems. Especially in SMK Negeri 2 Luwu which has not implemented a website-based system. This is because the library of SMK Negeri 2 Luwu still uses a manual system. As in the process of borrowing or returning books, which is still done by recording in the borrowing book. Besides that, when there are new books added, the librarian does not record the book data, only gives the ID to the book and immediately stores it on the appropriate shelf in the book category, so there is no regular book collection here.

Another obstacle is that if there are library members who will borrow books, it will be difficult to search for books on the bookshelves. In making reports, librarians still have problems because they have to take a long time to record and present reports where the officer must rewrite the report by recording existing borrowing data to be given to the principal.

\subsection{Design an Build}

Design and Build is the initial stage of making sketches and forms that have never been made at all and then managed to become a picture or sketch that has the desired function (Fajriya, et al. 2017). Design is an effort to make software that is translated from the results of the analysis so that it can create a new system or an existing system can be repaired. (Samania, et al. 2020). 


\subsection{Library}

The library is a room containing books that are neatly arranged which can usually be found in schools or in certain cities (Fatimah \& Elmasari, 2018). Libraries are centers of learning activities in educational institutions, many institutions realize that having a library within the scope of a school is one of the progress and added value in the morning of education for students, teachers and others (Pasaaribu, 2021).

\subsection{Unified Modeling Language (UML)}

UML (Unified Modelling Language) is a standard language that is widely used in the industrial world for defining requirements, making analysis and design, and describing architecture in object-oriented programming (Salahuddin, 2015). UML is one of the tools/models used for system design or for developing object-oriented systems. Writing standards in UML are in the form of blueprints in the form of writing objects or classes, making it easier for developers to build systems or applications according to the existing design (Sonata \& Sari, 2019).

\subsection{Web}

Web atau World Wide Web $(W W W)$ is a collection of pages that can display information either text, images, animations by using a web browser. Sir Timo-thy John "Tim" Berners-Lee in 1980 was the inventor of the British web (Fatimah \& Elmasari, 2018). The web is an application tool that aims to display page files so that users can access them via the internet network (Destiningrum \& Adrian, 2017).

Website or abbreviated as web, can be interpreted as a collection of pages that can contain information in the form of text, video, audio, images, animations available through the internet network (Josi, 2017).

A collection of content that can display information in the form of moving or still images, text, sound, animation, or a combination of all of them that are interrelated either in dynamic or static form and are connected to the internet network. (Batubara, 2012)

\section{METHOD}

The method used for this research is the waterfall system development method. The waterfall method is a sequential and gradual method that starts from observing, designing, programming, testing and implementation.

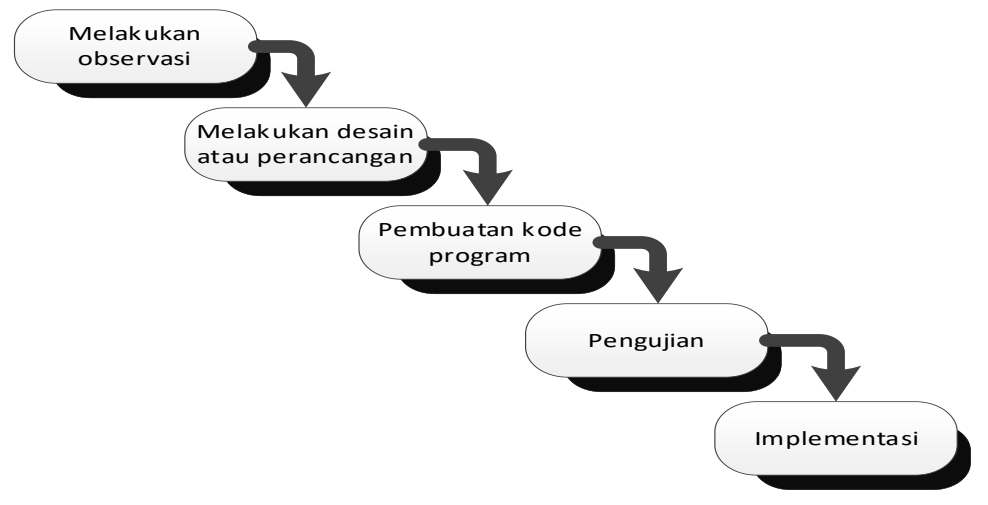

Figure 1. Waterfall Method

\subsection{System Plan}

The system running on the library at SMK Negeri 2 Luwu can be seen in Figure 2

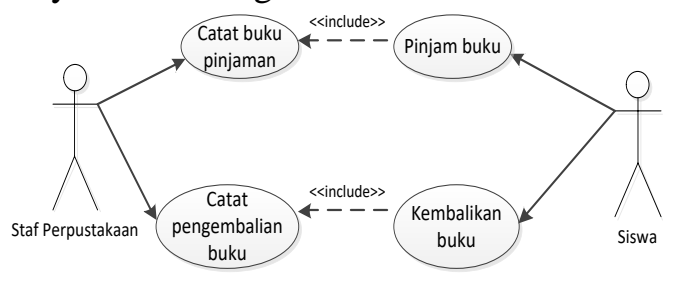

Figure 2. Sistem Berjalan 
In the system running on students who borrow books in the library and the data on borrowing books is recorded by the library staff. Likewise with the return of books, students who will return books will be recorded by the library staff.

The analysis of the proposed system in this study can be seen in the image below:

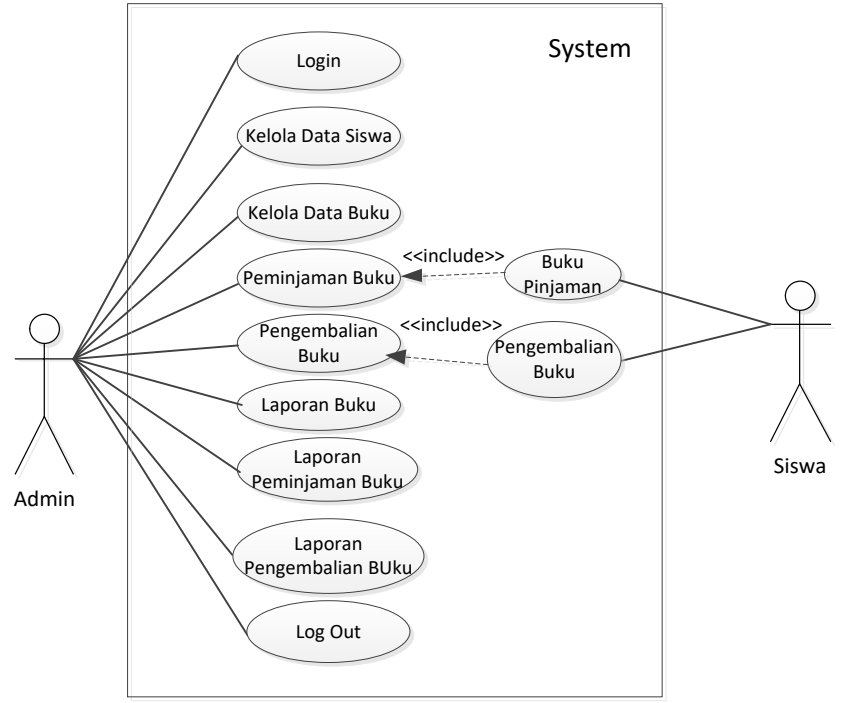

Figure 3. Proposed system analysis

\subsection{Analysis}

Analysis of the proposed system or procedure is to describe systematically the activities that occur in the system. In the proposed system, the admin can access all existing systems such as logging in, managing student data, managing book data, managing book lending transactions, managing book return transactions, and making book data reports. For students can see borrow books and return books.

\subsection{Login Page Plan Design}

The design below is the design of the library information system login page at the State Vocatio High School (SMK) 2 Luwu:

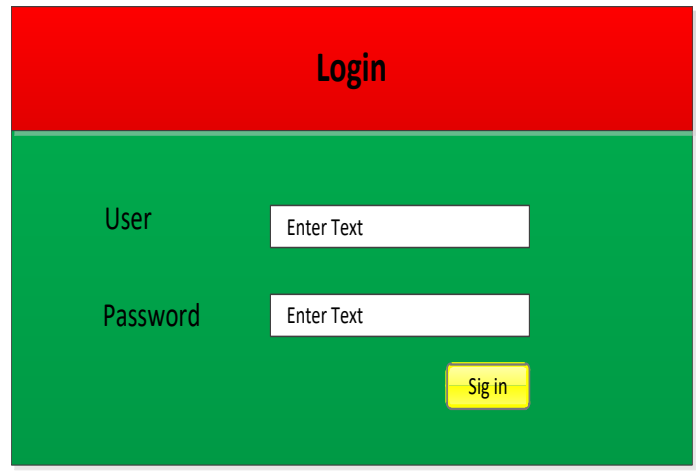

Figure 4. Login Page Plan Design

\subsection{Admin Menu Design Display}

Below is the admin menu page design on the library information system at the State 2 Luwu Vocational High School (SMK): 


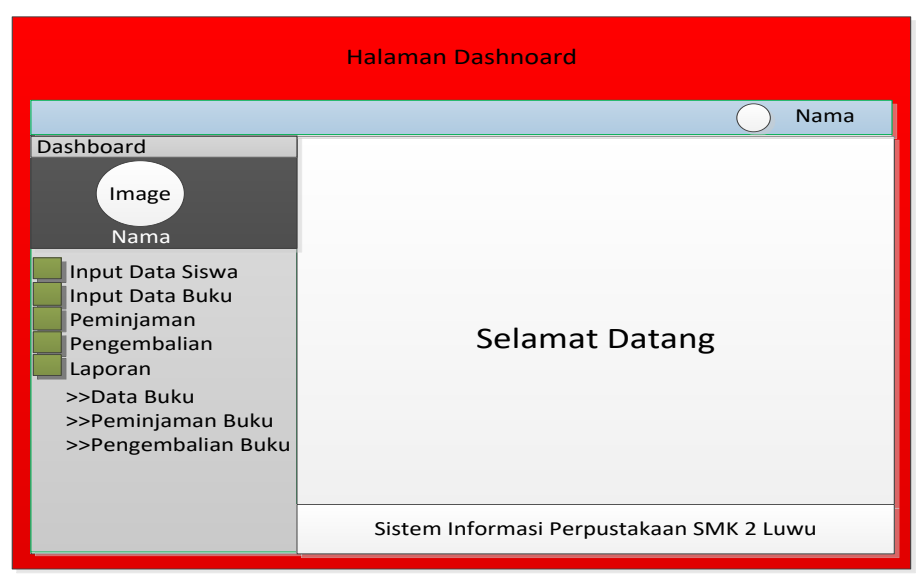

Figure 5. Admin Menu Design Display

\subsection{Student Data Input Design}

Below is the design of student data input on the library information system at the State 2 Luwu Vocational Hig School (SMK):

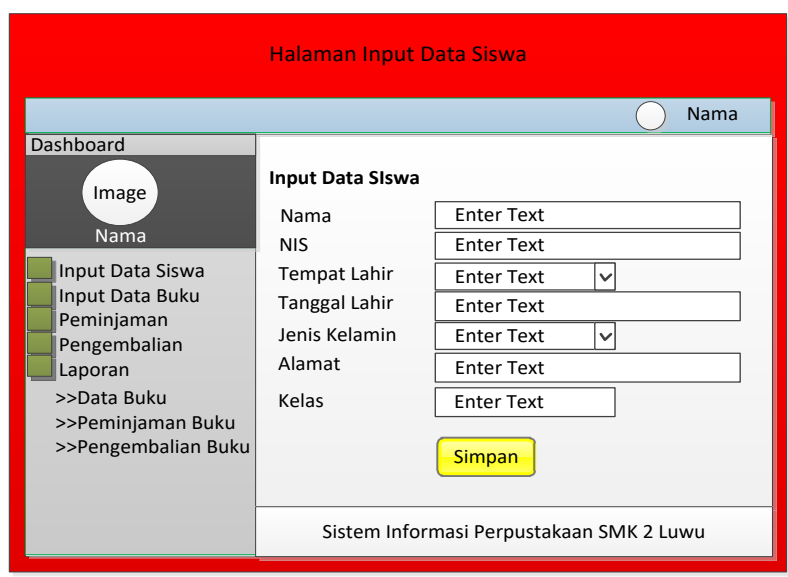

Figure 6. Student Data Input Design

\section{DISCUSSION}

\subsection{Login Page}

The login page is the first page that appears when running this system, here is the login page:

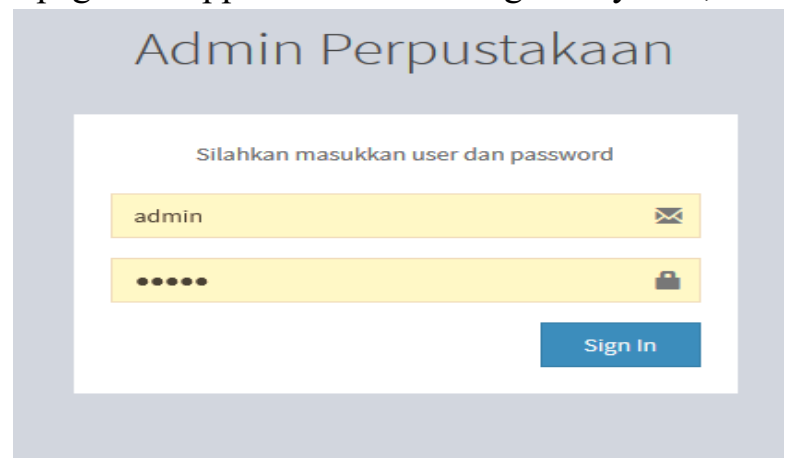

Figure 7. Login Page Display 


\subsection{Dashboard Appereance Page}

The admin dashboard page display is the initial view when the admin successfully logs in, for more details, it can be seen in the image below:

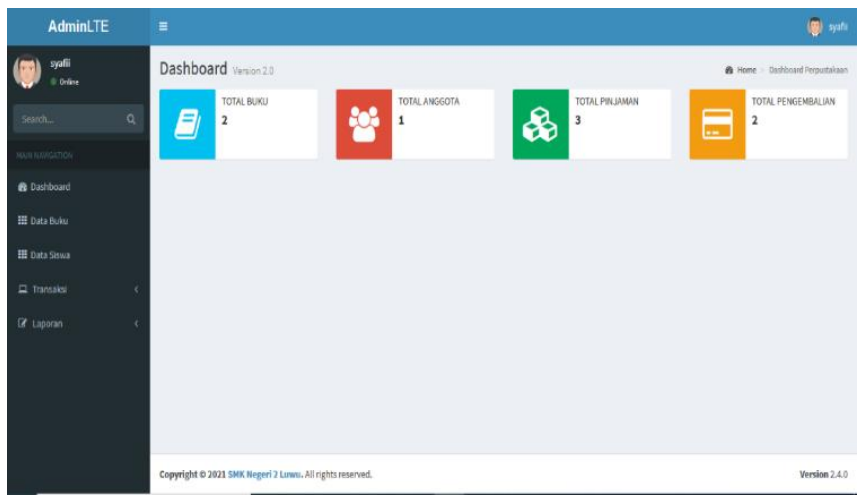

Figure 8. Tampilan Halaman Dashboard

\subsection{Book Input Page Display}

The book input page display is a display for managing book data such as data input, editing data and deleting data, for more details, see the image below:

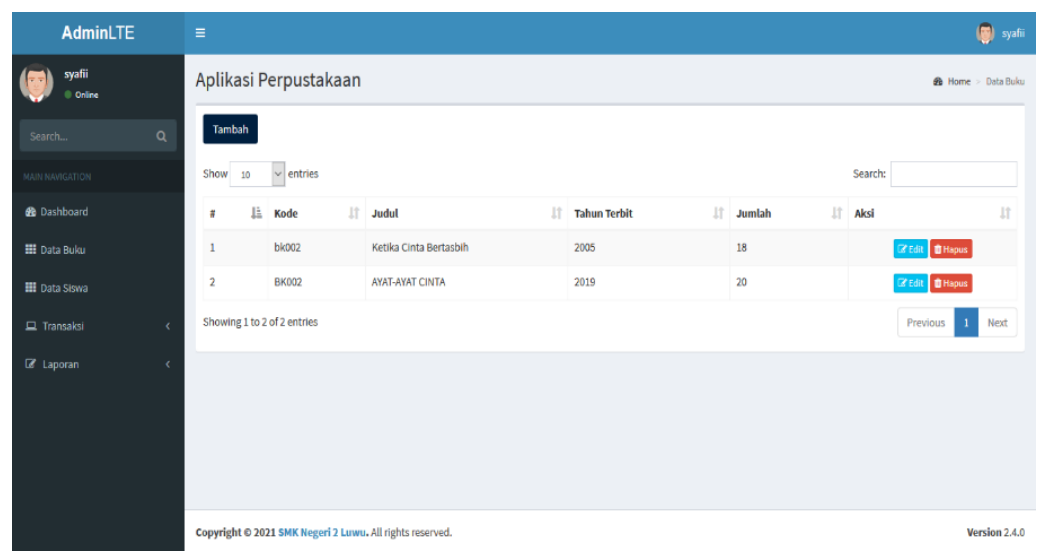

Figure 9. Book Input Page Display

\subsection{Student Input Page Display}

The student input page display is a display for managing student data such as data input, editing data and deleting data, for more details, see the image below:

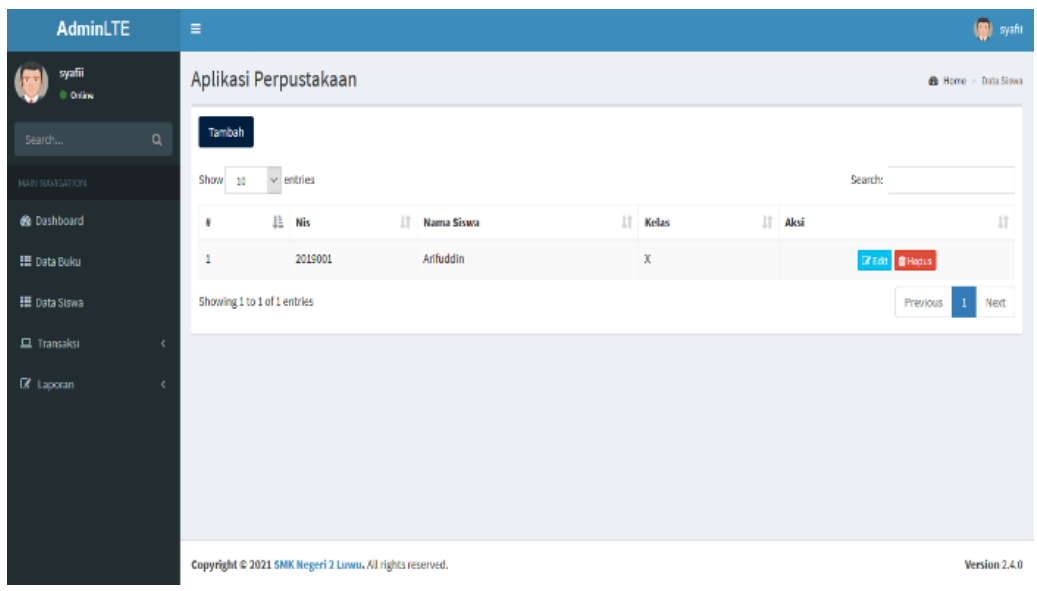

Figure 10. Student Input Page Display 


\subsection{Loan Page Display}

The borrowing page display is a display for borrowing books, for more details, see the image below:

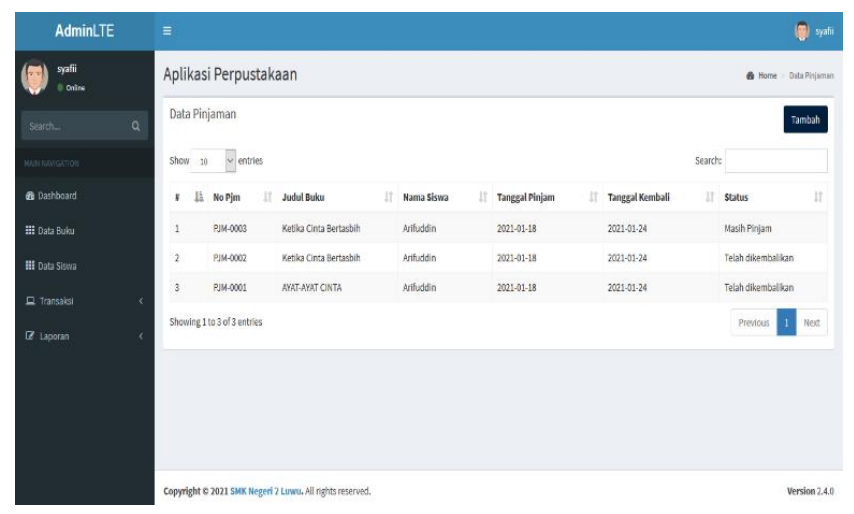

Figure 11. Loan Page Display

\subsection{Return Page Display}

The return page display is a display for returning books, for more details, see the figure below:

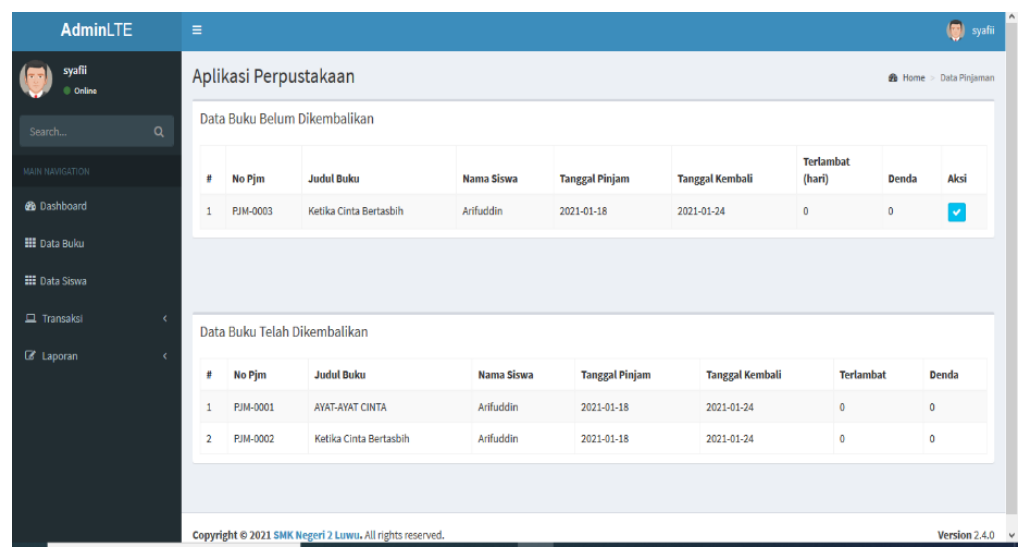

Figure 12. Return Page Display

\subsection{Book Stock Report Page Display}

The book stock report page display is a display for printing book stock reports, for more details, see the figure below:

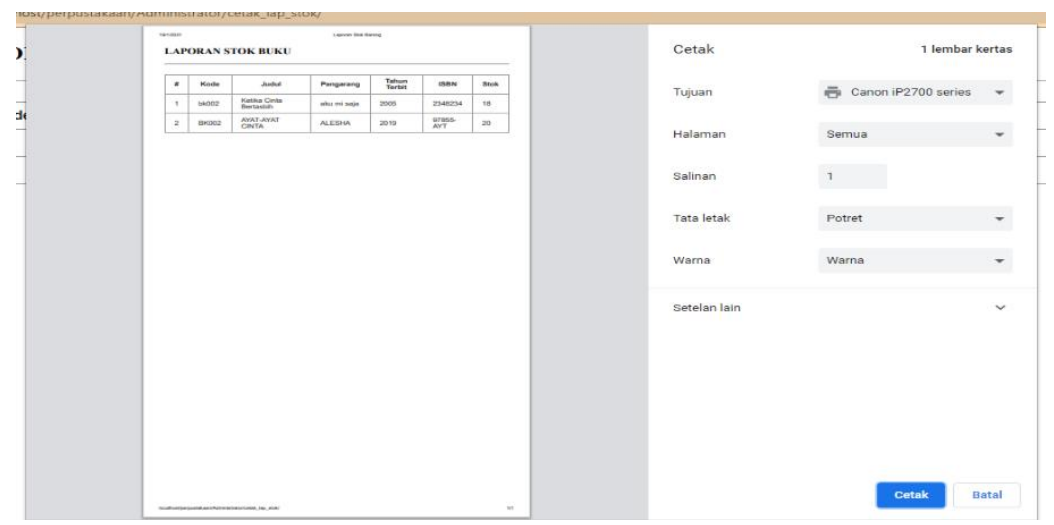

Figure 13. Book Stock Report Page Display 


\subsection{Loan Report Page Display}

The loan report page display is a display for printing loan reports, for more details, see the figure below:

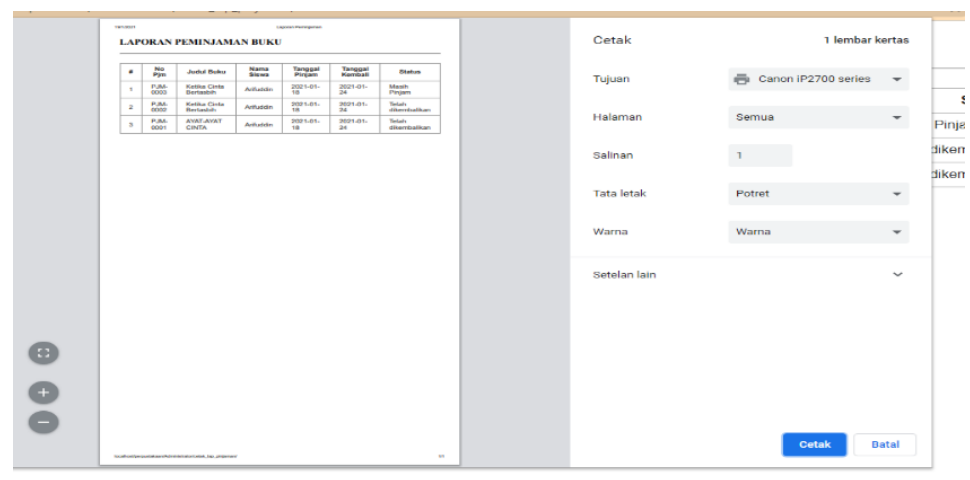

Figure 14. Loan Report Page Display

\subsection{Returns Report Page Display} below:

The return report page display is the display for printing the return report, for more details, see the image

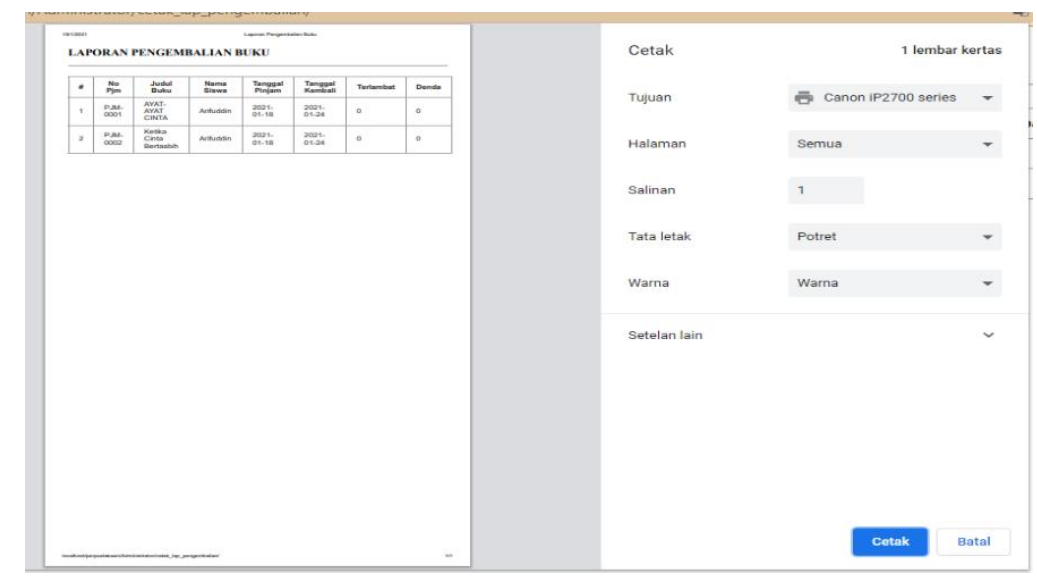

Figure 15. Returns Report Page Display

\section{KESIMPULAN}

Based on the discussion about the web-based school library design, the conclusions of this study are as follows:

1. The design of the library based at SMK Negeri 2 Luwu is designed using the UML model

2. The design of the library information system at SMK Negeri 2 Luwu was built using the PHP programming language and MySQL database and HTML as a markup language.

3. This library system has several pages including login page, dashboard page, book page, student page, loan page, return page, book stock report page, loan report page, return report page

\section{REFERENCE}

Apriyanto, A., \& Berlian, B. (2018). Sistem Informasi Perpustakaan Berbasis Web pada Fakultas Teknik Universitas Andi Djemma Palopo. PENA TEKNIK: Jurnal Ilmiah Ilmu-Ilmu Teknik, 3(2), 157-168.

Batubara, F. A. (2012). Perancangan Website Pada PT. Ratu Enim Palembang. Jurusan Teknik Elektro, 7, 16-27.

Dani, A. A. H., \& Kariadi, F. F. (2018). Sistem Informasi Penggajian (Studi Kasus: kantor Ratona Televisi Palopo). PENA TEKNIK: Jurnal Ilmiah Ilmu-ilmu Teknik, 3(2), 147-156.

Destiningrum, M., \& Adrian, Q., J. (2017). Sistem Informasi Penjadwalan Dokter Berbassis Web Dengan Menggunakan Framework Codeigniter (Studi Kasus: Rumah Sakit Yukum Medical Centre). TEKNOINFO, 11, 30-37.

Fajriya, Josi, A., \& Fisika, T. (2017). Rancang Bangun Sistem Informasi Tender Karet Desa Jungai Menggunakan Metode Waterfall. Jurnal SISFOKOM, 6, 111-115. 
Fatimah, \& Elmasari. (2018). Perancangan Sistem Informasi Perpustakaan Berbasis Web Untuk SMA Islam Sunan Gunung Jati. Jurnal Ilmiah Penelitian dan Pembelajaran Informatika, 3, 130-137.

Firman, Wowor, \& Najoan. (2016). Sistem Informasi Perpustakaan Online Berbasis Web. E-journal Teknik Elektro dan Komputer, 5, 29-36.

Hadi, A. (2020). Analisis Dan Perancangan Sistem Informasi Penjualan Pulsa Pada Toko Lumbung Buana Cellular. PENA TEKNIK: Jurnal Ilmiah Ilmu-Ilmu Teknik, 5(1), 19-30.

Hutagalung, \& Arif. (2018). Rancang Bangun Sistem Informasi Perpustakaan Berbasis Web Pada SMK Citra Negara Depok. Jurnal Rekayasa Informasi, 7, 13-22.

Josi, A. (2017). Penerapan Metode Prototiping Dalam Pembangunan Website Desa (Studi Kasus Desa Sugihan Kecamatan Rambang). Jurnal Teknologi Informasi, 9, 50-57.

Pasaaribu. (2021). Perancangan Sistem Informasi Perpustakaan Berbasis Web Di SMK Plus Pratama Adi Bandung. Jurnal Ilmiah Teknologi Informasi Terapan, 7, 148-158.

Salahuddin, \& Rosa. (2015). Rekayasa Perangkat Lunak Terstruktur dan Berorientasi Objek. Bandung: Informatika.

Samania, N., Nirsal, Fa'rifah, R., Y. (2020). Rancang Bangun Aplikasi E-Voting Pemilihan Ketua Umum Himpunan Mahasiswa Informatika (HMTI) Universitas Cokroaminoto Palopoberbasis Website. Jurnal Ilmiah d'Computare, 10, 29-53.

Sonata, F., \& Sari, V. W. (2019). Pemanfaatan UML (Unified Modeling Language) Dalam Perancangan Sistem Informasi E-Commerce Jenis Customer-To-Customer. Jurnal Komunikasi, Media dan Informatika, 8, 22-31.

Suppa, R., \& Saldi, T. (2018). Sistem Informasi Indekos Berbasis Web. PENA TEKNIK: Jurnal Ilmiah Ilmu-Ilmu Teknik, 3(2), 139-146. 